\title{
Substrate and irrigation scheme on the growth of Parapiptadenia rigida (angico-vermelho) seedlings
}

\author{
Diferentes substratos e regimes de rega no desenvolvimento \\ de mudas de Parapiptadenia rigida
}

\author{
Adriana Falcão Dutra ${ }^{I}$ Maristela Machado Araujo ${ }^{I I}$ Felipe Turchetto $^{I^{*}}$ \\ Daniele Guarienti Rorato ${ }^{I}$ Suelen Carpenedo Aimi ${ }^{I}$ \\ Daniele Rodrigues Gomes ${ }^{I}$ Toshio Nishijima ${ }^{I I I}$
}

\section{ABSTRACT}

Parapiptadenia rigida (angico-vermelho) is a native arboreal species widely found in central and southern Brazil and is indicated for restoration of degraded areas due to its high plasticity to light gradients and ease adaptation to degraded environments. However, there is still a lack of information on this species regarding the production of quality seedlings, as well as the rational use of the resources involved. Thus, the objective of this study was to evaluate the effects of different substrates and irrigation schemes in the development of $\boldsymbol{P}$. rigida seedlings. The experimental design used was randomized blocks, in a factorial scheme with split plots, with four substrate formulations $(100 \%$ peat; $80 \%$ peat $+20 \%$ carbonized rice husk (CRH); $60 \%$ peat $+40 \% \mathrm{CRH} ; 40 \%$ peat $+60 \% \mathrm{CRH}$ ) and six irrigation schemes $\left(4 ; 8 ; 12 ; 16 ; 20\right.$ and $\left.24 m m . d a y^{-1}\right)$. At 180 days after emergence, the following parameters were evaluated: height, stem diameter, height and stem diameter ratio, shoot dry weight, root dry weight, total dry weight and Dickson Quality Index. Use of substrate composed of $80 \%$ peat $+20 \%$ carbonized rice husk and/or $100 \%$ peat, combined with irrigation scheme of $4 \mathrm{~mm}$ day ${ }^{-1}$, resulted in the best growth of $\boldsymbol{P}$. rigida seedlings.

Key words: Parapiptadenia rigida, irrigation, production of seedlings.

\section{RESUMO}

Parapiptadenia rigida (angico-vermelho) é uma espécie arbórea nativa amplamente encontrada na região central e sul do Brasil, é indicada para restauração de áreas degradadas em virtude de sua alta plasticidade a gradientes de luz e facilidade de adaptação a ambientes degradados. No entanto, a espécie ainda carece de informações no que se refere a produção de mudas de qualidade, bem como, a utilização de forma racional dos recursos envolvidos. Dessa forma, esse estudo teve por objetivo avaliar os efeitos de diferentes substratos e regimes de rega no desenvolvimento de mudas de $\boldsymbol{P}$. rigida. $O$ delineamento experimental utilizado foi blocos ao acaso, em esquema fatorial com parcela subdividida, considerando quatro formulações de substratos (100\% turfa; $80 \%$ turfa $+20 \%$ casca de arroz carbonizada (CAC); $60 \%$ turfa + $40 \%$ CAC; $40 \%$ turfa $+60 \%$ CAC) e seis regimes de rega $(4 ; 8$; 12; 16; 20 e 24mm.dia ${ }^{-1}$ ). Aos 180 dias após a emergência, foram avaliados os seguintes parâmetros morfológicos: altura, diâmetro do coleto, relação altura e diâmetro do coleto, massa seca aérea, massa seca radicular, massa seca total e indice de qualidade de Dickson. Constatou-se que a utilização de substrato composto por $80 \%$ turfa $+20 \%$ casca de arroz carbonizada elou $100 \%$ turfa, combinado com o regime de rega de $4 \mathrm{~mm}$.dia ${ }^{-1}$, proporcionam o maior crescimento das mudas de P. rigida.

Palavras-chave: Parapiptadenia rigida, irrigação, produção de mudas.

\section{INTRODUCTION}

Parapiptadenia rigida Benth (angicovermelho), of the Fabaceae family, is a semi-heliophile species that is low temperature tolerant (ORTEGA, 1995). It is a pioneer species, generally appearing during primary succession (BACKES \& IRGANG, 2009) to initial secondary succession (VACCARO et al., 1999). As it is highly plastic to light gradients, it is suitable for plantations under both reduced light intensities and full sunlight (CARVALHO, 2003).

The importance of the species in the recovery of degraded areas is due to several

\footnotetext{
IPrograma de Pós-graduação em Engenharia Florestal, Centro de Ciências Rurais (CCR), Universidade Federal de Santa Maria (UFSM), 97105-900, Santa Maria, RS, Brasil. E-mail: felipe.turchetto@gmail.com. "Corresponding author.

IIDepartamento de Ciências Florestais, Centro de Ciências Rurais (CCR), Universidade Federal de Santa Maria (UFSM), Santa Maria, RS, Brasil.

IIIDepartamento de Agronomia, Centro de Ciências Rurais (CCR), Universidade Federal de Santa Maria (UFSM), Santa Maria, RS, Brasil. Received 11.27.14 Approved 12.01.15 Returned by the author 03.02.16 CR-2014-1732.R3
} 
factors: a) its flowering attracts pollinating insects (ALMEIDA et al., 2010), serving as a food source for them, which promotes diversification of the area; b) its rapid and highly successful germination, in either the presence or absence of light (MONDO et al., 2008), gives it a higher chance of regenerating naturally; and c) it participates in symbiotic associations with microbes (PATREZE \& CORDEIRO, 2004), contributing to improvements in soil health. In addition, the timber is of excellent quality; dense $\left(0.89\right.$ to $\left.0.95 \mathrm{~g} . \mathrm{cm}^{-3}\right)$ and naturally durable, is highly valued for rural construction, railroad ties, and carpentry (CARVALHO, 2003; BACKES \& IRGANG, 2009). Given the economic and ecological importance of $\boldsymbol{P}$. rigida, studies that focus on the quality of its seedlings, in particular addressing factors that interfere in their development, are required. Yet there is a lack of such studies.

In the State of Rio Grande do Sul, through Decree No. 47.137/2010, forest restoration was established with native species in areas of permanent preservation, legal reserves, and forestry compensation (RIO GRANDE DO SUL, 2010). Thus, it is of fundamental importance to define protocols and strategies to production of quality seedlings in less time, under conditions accessible to small and medium-sized rural producers, as this sector of the public is one of the most interested in this type of input.

In this context, the success of both conservation plantations and those with commercial purposes is dependent upon the seedlings quality. According to CARNEIRO (1995), the use of highquality seedlings is a determinant factor in survival and initial post-planting growth, reducing the time of weed control in newly deployed areas. CALDEIRA et al. (2013), point to substrate as a constraint of standard of quality of the seedlings in a nursery; ideal substrate should match the plant's needs with regard to consistency, structure, water retention capacity, and porosity.

The water used in irrigation is another factor that must be taken into account when one wishes to obtain quality seedlings, because the lack or excess thereof may limit development (LOPES, 2004). According to AZEVEDO (2003), the increase in the quantity of water required for irrigation accompanied by the decrease in its availability and the high cost of energy required have increased interest in rationing this resource, in order to minimize losses. So, the present study aimed to evaluate the effects of different substrates and irrigation schemes in the growth and seedling quality of $\boldsymbol{P}$. rigida.

\section{MATERIALS AND METHODS}

The experiment was carried out in the Forest Nursery of the Department of Forest Sciences of the Universidade Federal de Santa Maria (29 $43^{\circ}$ ' $\mathrm{S}$ and $53^{\circ} 43^{\prime} \mathrm{W}$ ), at an altitude of approximately 90 meters above the sea level. The climate in that area is Cfa type, according to the Köppen classification; annual average rainfall is between 1,900 to $2,200 \mathrm{~mm}$, with rains distributed uniformly over the year (ALVARES et al., 2013).

The ripe fruits of $\boldsymbol{P}$. rigida were collected in September 2009 from 28 seed trees located in forest remnants in the region of Santa Maria. After collection, the seeds were processed and homogenized, forming a single batch, and stored in a cold chamber at a temperature of $\pm 8^{\circ} \mathrm{C}$ with relative humidity around $80 \%$. They remained at these conditions, stored in polyethylene bags, for 15 months.

For the experimental design, randomized, factorial blocks were established and divided into sub-plots. In the main plots, six irrigation schemes were randomized, and in each of the sub-plots one of four substrates (S) composed of different proportions of peat and carbonized rice husk (CRH) was used as growth medium $(\mathrm{S} 1=100 \%$ peat; $\mathrm{S} 2=80 \%$ peat $+20 \%$ $\mathrm{CRH} ; \mathrm{S} 3=60 \%$ peat $+40 \% \mathrm{CRH}$ and $\mathrm{S} 4=40 \%$ peat + $60 \% \mathrm{CRH}$ ), with four replicates per treatment. The plots contained 24 plants each; 9 central individuals were evaluated and 4 individuals were used for destructive analyses.

Sowing was performed directly in the substrates described above, with three seeds each planted in $110 \mathrm{~cm}^{3}$ polypropylene cone shells, packed in plastic trays suspended $16 \mathrm{~cm}$ from the soil surface, and maintained in the greenhouse. After approximately 30 days of growth, thinning was performed, leaving only one seedling per polypropylene cone. These seedlings were grown in the greenhouse with $4 \mathrm{~mm} \mathrm{~d}^{-1}$ irrigation for $60 \mathrm{~d}$ and were thereafter submitted to different irrigation schemes in the open air.

Before the installation of the experiment, physical and chemical analyses of substrates were performed (Table 1) in the Laboratory for Plant Substrate Analysis, part of the Fundação Estadual de Pesquisa Agropecuária.

Irrigation schemes were distributed in different frequencies and daily schedules, seeking to optimize the automation of the irrigation system. These were: $\mathrm{R} 4,4 \mathrm{~mm} \mathrm{~d}^{-1}(2 \mathrm{~mm}$ at 8:00 and 13:00h); R8, $8 \mathrm{~mm} \mathrm{~d}^{-1}(2 \mathrm{~mm}$ at 8:00 and 13:00 and $4 \mathrm{~mm}$ at $15: 20 \mathrm{~h})$; R12, $12 \mathrm{~mm} \mathrm{~d}^{-1}(4 \mathrm{~mm}$ at 8:30, 12:30, 
Table 1 - Physical and chemical attributes of substrates, Forest Nursery, DCFL, UFSM.

\begin{tabular}{lcccclll}
\hline Substrate & WD $\left(\mathrm{kg} / \mathrm{m}^{3}\right)$ & PS $\%$ & RAW $\%$ & EC $(\mathrm{dS} / \mathrm{m})$ & Condition & $\mathrm{pH}$ & Condition \\
\hline S1 & 392 & 22.6 & 32.1 & 0.54 & Normal & 6.0 & Appropriate \\
S2 & 278 & 30.6 & 23.7 & 0.41 & Normal & 6.1 & Appropriate \\
S3 & 276 & 45.8 & 19.3 & 0.30 & Low & 6.3 & Appropriate \\
S4 & 279 & 43.3 & 17.1 & 0.21 & Low & 6.6 & High \\
\hline
\end{tabular}

S1 - $100 \%$ peat; S2 - $80 \%$ peat $20 \%$ carbonized rice husk (CRH); S3 - $60 \%$ peat $40 \%$ CRH; S4 - $40 \%$ peat $60 \%$ CRH; WD - wet density; PS - pore space; RAW - readily available water; EC - electrical conductivity.

and 15:00h); R16, $16 \mathrm{~mm} \mathrm{~d}^{-1}(4 \mathrm{~mm}$ at 7:45, 11:30, 14:00, and 16:45h); R20, 20 $\mathrm{mm} \mathrm{d}^{-1}(4 \mathrm{~mm}$ at 8:30, $12: 30$, and $15: 00 \mathrm{pm}$ and $8 \mathrm{~mm}$ at $16: 45 \mathrm{~h}$ ) and R24, $24 \mathrm{~mm} \mathrm{~d}^{-1}(4 \mathrm{~mm}$ at $7: 45,11: 30,14: 00$, and 16:45h and $8 \mathrm{~mm}$ at $17: 30 \mathrm{~h})$.

At 180 days after emergence, the following characteristics were measured: height $(\mathrm{H})$, stem diameter (SD), height and stem diameter ratio (H/SD), shoot dry weight (SDW), root dry weight (RDW), total dry weight (TDW), and Dickson Quality Index (DQI).

Height was obtained with the aid of a millimeter ruler, taking as the standard the apical bud of the plant, and the diameter of the stem was measured with a digital caliper (accuracy of 0.01 $\mathrm{mm}$ ). The values of dry weight were determined by weighing, after drying the material for approximately $72 \mathrm{~h}$ in a forced air oven at $70^{\circ} \mathrm{C}$. The DQI was obtained by equation 1 , in accordance with GONÇALVES et al. (2000).

$D Q I=(T D W) /(H / S T+S D W / R D W)$

\section{Equation 1}

For this equation, DQI $=$ Dickson Quality Index, $\mathrm{H}=$ height $(\mathrm{cm}), \mathrm{SD}=$ stem diameter $(\mathrm{mm})$, TDW = total dry weight (g), SDW = shoot dry weight $(\mathrm{g})$, and $\mathrm{RDW}=$ root dry weight $(\mathrm{g})$.

The data were analyzed according to the model $\mathrm{Y}_{\mathrm{ijk}}=\mathrm{m}+\mathrm{b}_{\mathrm{i}}+\mathrm{rg}_{\mathrm{j}}+(\mathrm{brg})_{\mathrm{ij}}+\mathrm{s}_{\mathrm{k}}+(\mathrm{rgs})_{\mathrm{jk}}+\delta_{\mathrm{ijk}}$, where $Y_{i j k}$ is the observed value for each seedling evaluated, $m$ is the global average, $b_{i}$ is the random block effect, $\mathrm{rg}_{\mathrm{j}}$ is the fixed effect of the irrigation scheme, $(\mathrm{brg})_{\mathrm{ij}}$ is the main plots, $\mathrm{s}_{\mathrm{k}}$ is the fixed effect of substrate, $(\mathrm{rgs})_{\mathrm{ik}}$ is the effect of the interaction between the irrigation scheme and substrate, and $\delta_{\mathrm{ijk}}$ is the error of the sub-plots. Subsequently, an analysis of assumptions was performed, followed by analysis of variance and the comparison of means by the Scott-Knott test $(\mathrm{P}=0.05)$ using the SISVAR software v. 5.3 (FERREIRA, 2011).

\section{RESULTS AND DISCUSSION}

The interaction between the irrigation schemes and different substrates was significant only for the variables height $(\mathrm{H})$, stem diameter (SD), and H/SD ratio. Thus, for these variables, the irrigation scheme adopted will depend on the type of substrate used, which is influenced by the proportion of each material.

The height and stem diameter variables in substrates S1 (100\% peat) and S2 (80\% peat $+20 \% \mathrm{CRH})$ presented the best results when the R4 irrigation scheme was used $\left(4 \mathrm{~mm} \mathrm{~d}^{-1}\right)$. However, using the S4 substrate $(40 \%$ peat $+60 \%$ $\mathrm{CRH})$ the best results in the growth in height were obtained with irrigation schemes R16 $\left(16 \mathrm{~mm} \mathrm{~d}^{-1}\right)$ and R20 (20 $\left.\mathrm{mm} \mathrm{d}^{-1}\right)$ (Table 2).

LOPES et al. (2007) reported that Eucalyptus grandis seedlings grown in substrates composed of pine bark, coal, peat, and vermiculite at irrigation schemes of 12 and $14 \mathrm{~mm} \mathrm{~d}^{-1}$, applied three times a day, developed best. TSUKAMOTO FILHO et al. (2013), obtained better development of Myracrodruon urundeuva Allemão seedlings when they were submitted to an irrigation level of $12 \mathrm{~mm} \mathrm{~d}^{-1}$ applied twice a day.

Lower water requirement of $\boldsymbol{P}$. rigida is probably related to its high adaptability to different conditions as described by CARVALHO (2003), who also explained the need to avoid planting it in excessively humid soils. The adaptation of $\boldsymbol{P}$. rigida to environments with low water availability is achieved by osmotic adjustment to sugars accumulation, amino acids, and alcohols (MORGAN, 1984) enabling the maintenance of cellular turgor and growth even with low leaf water potential. Thus, it can be inferred that the species is able to use water efficiently, allowing enhanced growth even under reduced water supply. 
Table 2 - Average values of height (H), stem diameter (SD), and H/SD of seedlings of $\boldsymbol{P}$. rigida according to irrigation scheme (IS) and types of substrate.

\begin{tabular}{|c|c|c|c|c|c|c|}
\hline \multirow{2}{*}{ Variable } & \multirow[t]{2}{*}{ IS } & \multicolumn{4}{|c|}{ 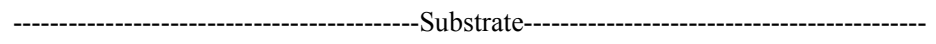 } & \multirow{2}{*}{ Average } \\
\hline & & $\mathrm{S} 1$ & $\mathrm{~S} 2$ & S3 & S4 & \\
\hline \multirow{9}{*}{$\mathrm{H}(\mathrm{cm})$} & R4 & $29.28 \mathrm{Aa}$ & $29.85 \mathrm{Aa}$ & $23.67 \mathrm{Ba}$ & $15.45 \mathrm{Cb}$ & 24.56 \\
\hline & $\mathrm{R} 8$ & $23.34 \mathrm{Ab}$ & $24.43 \mathrm{Ab}$ & $20.77 \mathrm{Bb}$ & $15.05 \mathrm{Cb}$ & 20.89 \\
\hline & $\mathrm{R} 12$ & $21.74 \mathrm{Bb}$ & $24.72 \mathrm{Ab}$ & $20.74 \mathrm{Bb}$ & $16.67 \mathrm{Cb}$ & 20.96 \\
\hline & $\mathrm{R} 16$ & $23.26 \mathrm{Ab}$ & $24.56 \mathrm{Ab}$ & $19.06 \mathrm{Bc}$ & $17.12 \mathrm{Ca}$ & 21.00 \\
\hline & $\mathrm{R} 20$ & $22.96 \mathrm{Bb}$ & $25.85 \mathrm{Ab}$ & $20.89 \mathrm{Bb}$ & $18.25 \mathrm{Ca}$ & 21.98 \\
\hline & $\mathrm{R} 24$ & $23.27 \mathrm{Ab}$ & $24.64 \mathrm{Ab}$ & $22.37 \mathrm{Aa}$ & $15.35 \mathrm{Bb}$ & 21.40 \\
\hline & Average & 23.98 & 25.67 & 21.25 & 16.86 & \\
\hline & \multicolumn{2}{|c|}{$C V(\%)=14.56$} & \multicolumn{4}{|c|}{$F(P) \mathrm{IS}=47.401(0.000)$} \\
\hline & \multicolumn{2}{|c|}{$F(P)$ IS*substrate $=5.082(0.000)$} & \multicolumn{4}{|c|}{$F(P)$ substrate $=312.84(0.000)$} \\
\hline \multirow{9}{*}{$\mathrm{SD}(\mathrm{mm})$} & $\mathrm{R} 4$ & $4.02 \mathrm{Aa}$ & $3.99 \mathrm{Aa}$ & $3.37 \mathrm{Ba}$ & $2.76 \mathrm{Ca}$ & 3.54 \\
\hline & $\mathrm{R} 8$ & $3.20 \mathrm{Ac}$ & $3.28 \mathrm{Ab}$ & $3.19 \mathrm{Aa}$ & $2.62 \mathrm{Ba}$ & 3.07 \\
\hline & $\mathrm{R} 12$ & $3.15 \mathrm{Ac}$ & $3.17 \mathrm{Ac}$ & $2.80 \mathrm{Bb}$ & $2.72 \mathrm{Ba}$ & 2.96 \\
\hline & R16 & $3.07 \mathrm{Ac}$ & $3.10 \mathrm{Ac}$ & $2.89 \mathrm{Bb}$ & $2.72 \mathrm{Ba}$ & 2.94 \\
\hline & $\mathrm{R} 20$ & $2.84 \mathrm{Ad}$ & $2.98 \mathrm{Ac}$ & $2.71 \mathrm{Ab}$ & $2.44 \mathrm{Ba}$ & 2.75 \\
\hline & $\mathrm{R} 24$ & $3.49 \mathrm{Ab}$ & $3.51 \mathrm{Ab}$ & $3.12 \mathrm{Ba}$ & $2.61 \mathrm{Ca}$ & 3.18 \\
\hline & Average & 3.29 & 3.34 & 3.02 & 2.65 & \\
\hline & \multicolumn{2}{|c|}{$C V(\%)=14.99$} & \multicolumn{4}{|c|}{$F(P)$ IS $=49.095(0.000)$} \\
\hline & \multicolumn{2}{|c|}{$F(P)$ IS* substrate $=5.119(0.000)$} & \multicolumn{4}{|c|}{$F(P)$ substrate $=103.98(0.000)$} \\
\hline \multirow{9}{*}{$\mathrm{H} / \mathrm{SD}$} & R4 & $7.39 \mathrm{Ab}$ & $7.56 \mathrm{Ac}$ & $7.07 \mathrm{Ab}$ & $7.19 \mathrm{Aa}$ & 7.31 \\
\hline & $\mathrm{R} 8$ & $7.35 \mathrm{Ab}$ & $7.51 \mathrm{Ac}$ & $6.66 \mathrm{Bb}$ & $5.87 \mathrm{Cb}$ & 6.85 \\
\hline & $\mathrm{R} 12$ & $7.04 \mathrm{Bc}$ & $7.85 \mathrm{Ab}$ & $7.42 \mathrm{Aa}$ & $6.89 \mathrm{Ba}$ & 7.30 \\
\hline & R16 & $7.57 \mathrm{Aa}$ & $7.92 \mathrm{Ab}$ & $6.68 \mathrm{Bb}$ & $6.19 \mathrm{Bb}$ & 7.11 \\
\hline & $\mathrm{R} 20$ & $8.08 \mathrm{Ba}$ & $8.67 \mathrm{Aa}$ & $7.76 \mathrm{Ba}$ & $6.49 \mathrm{Cb}$ & 7.78 \\
\hline & $\mathrm{R} 24$ & $6.77 \mathrm{Ac}$ & $7.14 \mathrm{Ac}$ & $7.21 \mathrm{Aa}$ & $5.93 \mathrm{Bb}$ & 6.76 \\
\hline & Average & 7.38 & 7.79 & 7.13 & 6.43 & \\
\hline & \multicolumn{2}{|c|}{$C V(\%)=14.88$} & & \multicolumn{2}{|c|}{$F(P)$ IS $=17.119(0.000)$} & \\
\hline & \multicolumn{2}{|c|}{$F(P)$ IS* substrate $=4.638(0.000)$} & & \multicolumn{2}{|c|}{$F(P)$ substrate $=61.805(0.000)$} & \\
\hline
\end{tabular}

$\mathrm{R} 4=4 \mathrm{~mm} \mathrm{~d}^{-1} ; \mathrm{R} 8=8 \mathrm{~mm} \mathrm{~d}^{-1} ; \mathrm{R} 12=12 \mathrm{~mm} \mathrm{~d}^{-1} ; \mathrm{R} 16=16 \mathrm{~mm} \mathrm{~d}^{-1} ; \mathrm{R} 20=20 \mathrm{~mm} \mathrm{~d}^{-1} ; \mathrm{R} 24=24 \mathrm{~mm} \mathrm{~d}^{-1} ; \mathrm{S} 1=100 \%$ peat; $2=80 \%$ peat and $20 \% \mathrm{CRH}$; S3 $=60 \%$ peat and $40 \% \mathrm{CRH}$; S4 $=40 \%$ peat and $60 \% \mathrm{CRH} ; \mathrm{H}=$ height; SD $=$ stem diameter; H/SD $=$ height $/$ stem diameter ratio; $F=$ Snedecor statistical test; $P=$ statistical probability. Averages followed by the same lowercase letter in the column and capital letter in the row do not differ by $5 \%$ by the Scott-Knott test.

The need for a greater volume of water when using a high proportion of components such as $\mathrm{CRH}$ in the substrate $(>20 \%)$ is related to physical and chemical characteristics of this culture medium (Table 1). Addition of CRH to the substrate increases macroporosity and reduces the water content readily available to the plant, as can be observed with substrate S4 (40\% peat $+60 \% \mathrm{CRH})$. Thus, it can be inferred that substrates with smaller proportions of $\mathrm{CRH}$ (S2, for example) provided adequate levels of readily available water; as a consequence, electrical conductivity is also increased. The result is higher mobility of nutrients in the substrate solution, and greater nutrient availability to the plant.
Values of the H/SD ratio ranged between 5.9 and 8.6 (Table 2). CARNEIRO (1995) considers this variable the one that best represents the balance in the growth of seedlings in the nursery, because it considers two characteristics in just one index. However, published values differ. According to CARNEIRO (1995), quality seedlings must present values between 5.4 and 8.1; for GONÇALVES et al. (2000), the values must be between 2.0 and 7.0, while for DAVIDE \& FARIA (2008) the values should not be lower than 8.3 .

Seedlings that present smaller stem diameter and elevated height are considered of lower quality when compared to those that have a lower 
height and larger diameter. Hence, the $\mathrm{H} / \mathrm{SD}$ ratio should be used in conjunction with other variables for the evaluation of the quality of forest seedlings (FONSECA et al., 2002). In addition, the ideal H/SD may not be generalized for all species, as each presents its own specific morphological characteristics. Thus, considering the values obtained for the other morphological variables, it is concluded that seedlings of $\boldsymbol{P}$. rigida with $\mathrm{H} / \mathrm{SD}$ values between 7.35 and 7.92 represent seedlings with appropriate quality.

For the variables shoot dry weight, root dry weight, and total dry weight, there was no interaction between the irrigation scheme and substrates. However, when substrate and irrigation scheme were analyzed separately for all dry weight a significant difference was observed (Table 3).

The seedlings produced in substrates $\mathrm{S} 1$ (100\% peat), S2 (80\% peat $+20 \% \mathrm{CRH})$, and S3 $(60 \%$ peat $+40 \% \mathrm{CRH})$ presented higher dry weight values, differing statistically from S4 (40\% peat + $60 \% \mathrm{CRH}$ ). As the proportion of $\mathrm{CRH}$ increased, the total dry weight of the seedlings decreased.

A significant difference was also observed for the irrigation schemes. On average, R4 (4mm $\left.\mathrm{d}^{-1}\right)$ and $\mathrm{R} 8\left(8 \mathrm{~mm} \mathrm{~d}^{-1}\right)$ accumulated more dry weight. These results corroborate the values obtained for $\mathrm{H}, \mathrm{SD}$, and $\mathrm{H} / \mathrm{SD}$, confirming that an irrigation level of $4 \mathrm{~mm} \mathrm{~d}^{-1}$ is suitable for the development

Table 3 - Average dry weight of $\boldsymbol{P}$. rigida seedlings according to irrigation scheme (IS) and substrate type.

\begin{tabular}{|c|c|c|c|c|c|c|}
\hline \multirow{2}{*}{ Variable } & \multirow{2}{*}{ IS } & \multicolumn{4}{|c|}{ 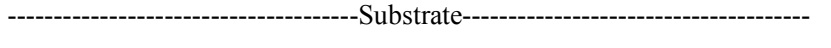 } & \multirow{2}{*}{ Average } \\
\hline & & $\mathrm{S} 1$ & $\mathrm{~S} 2$ & $\mathrm{~S} 3$ & S4 & \\
\hline \multirow{9}{*}{$\operatorname{SDW}(\mathrm{g})$} & $\mathrm{R} 4$ & 5.38 & 5.12 & 3.15 & 2.37 & $4.00 \mathrm{a}$ \\
\hline & $\mathrm{R} 8$ & 3.32 & 4.00 & 3.55 & 2.63 & $3.38 \mathrm{a}$ \\
\hline & $\mathrm{R} 12$ & 2.80 & 2.44 & 1.61 & 1.81 & $2.16 \mathrm{~b}$ \\
\hline & $\mathrm{R} 16$ & 2.39 & 2.35 & 2.66 & 2.42 & $2.46 \mathrm{~b}$ \\
\hline & $\mathrm{R} 20$ & 3.01 & 2.84 & 3.21 & 2.17 & $2.81 \mathrm{~b}$ \\
\hline & $\mathrm{R} 24$ & 3.21 & 3.33 & 3.88 & 1.37 & $2.95 \mathrm{~b}$ \\
\hline & Average & $3.35 \mathrm{~A}$ & $3.34 \mathrm{~A}$ & $3.01 \mathrm{~A}$ & $2.13 \mathrm{~B}$ & \\
\hline & \multicolumn{3}{|c|}{$C V(\%)=42.05$} & \multicolumn{3}{|c|}{$F(P)$ IS $=4.481(0.0013)$} \\
\hline & \multicolumn{3}{|c|}{$F(P)$ IS $*$ Substrate $=1.549(0.3311)$} & \multicolumn{3}{|c|}{$F(P)$ substrate $=5.143(0.0028)$} \\
\hline \multirow{9}{*}{ RDW (g) } & R4 & 5.38 & 5.12 & 3.15 & 2.37 & $4.00 \mathrm{a}$ \\
\hline & $\mathrm{R} 8$ & 3.32 & 4.00 & 3.55 & 2.63 & $3.38 \mathrm{a}$ \\
\hline & $\mathrm{R} 12$ & 2.80 & 2.44 & 1.61 & 1.81 & $2.16 \mathrm{~b}$ \\
\hline & $\mathrm{R} 16$ & 2.39 & 2.35 & 2.66 & 2.42 & $2.46 \mathrm{~b}$ \\
\hline & $\mathrm{R} 20$ & 3.01 & 2.84 & 3.21 & 2.17 & $2.81 \mathrm{~b}$ \\
\hline & $\mathrm{R} 24$ & 3.21 & 3.33 & 3.88 & 1.37 & $2.95 \mathrm{~b}$ \\
\hline & Average & $1.86 \mathrm{~A}$ & $1.85 \mathrm{~A}$ & $1.63 \mathrm{~A}$ & $1.07 \mathrm{~B}$ & \\
\hline & \multicolumn{3}{|c|}{$C V(\%)=46.82$} & \multicolumn{3}{|c|}{$F(P)$ IS $=3.399(0.0082)$} \\
\hline & \multicolumn{3}{|c|}{$F(P)$ IS $*$ Substrate $=1.323(0.2127)$} & \multicolumn{3}{|c|}{$F(P)$ substrate $=5.798(0.0013)$} \\
\hline \multirow{9}{*}{ The TDW (g) } & $\mathrm{R} 4$ & 8.34 & 7.63 & 4.63 & 3.50 & $6.03 \mathrm{a}$ \\
\hline & $\mathrm{R} 8$ & 5.43 & 6.38 & 5.79 & 3.96 & $5.39 \mathrm{a}$ \\
\hline & $\mathrm{R} 12$ & 4.29 & 3.65 & 2.54 & 2.97 & $3.37 \mathrm{~b}$ \\
\hline & $\mathrm{R} 16$ & 3.97 & 4.16 & 3.39 & 3.72 & $3.81 \mathrm{~b}$ \\
\hline & $\mathrm{R} 20$ & 4.45 & 4.73 & 5.29 & 3.21 & $4.42 \mathrm{~b}$ \\
\hline & $\mathrm{R} 24$ & 4.78 & 5.44 & 5.45 & 1.85 & $4.38 \mathrm{~b}$ \\
\hline & Average & $5.21 \mathrm{~A}$ & $5.20 \mathrm{~A}$ & $4.64 \mathrm{~A}$ & $3.21 \mathrm{~B}$ & \\
\hline & \multicolumn{3}{|c|}{$C V(\%)=39.37$} & \multicolumn{3}{|c|}{$F(P)$ IS $=4.833(0.0007)$} \\
\hline & \multicolumn{3}{|c|}{$F(P)$ IS $*$ Substrate $=1.366(0.1878)$} & \multicolumn{3}{|c|}{$F(P)$ substrate $=6.641(0.0005)$} \\
\hline
\end{tabular}

$\mathrm{R} 4=4 \mathrm{~mm} \mathrm{~d}^{-1} ; \mathrm{R} 8=8 \mathrm{~mm} \mathrm{~d}^{-1} ; \mathrm{R} 12=12 \mathrm{~mm} \mathrm{~d}^{-1} ; \mathrm{R} 16=16 \mathrm{~mm} \mathrm{~d}^{-1} ; \mathrm{R} 20=20 \mathrm{~mm} \mathrm{~d}^{-1} ; \mathrm{R} 24=24 \mathrm{~mm} \mathrm{~d}^{-1} ; \mathrm{S} 1=100 \%$ peat; S2 $=80 \%$ peat and $20 \% \mathrm{CRH}$; S3 $=60 \%$ peat and $40 \% \mathrm{CRH}$; S4 $=40 \%$ peat and $60 \% \mathrm{CAC}$; RDW $=$ root dry weight; SDW $=$ shoot dry weight; TDW $=$ total dry weight; $F=$ Snedecor statistical test; $P=$ statistical probability. Averages followed by the same lowercase letter in the column do not differ by $5 \%$ by the Scott-Knott test.

Ciência Rural, v.46, n.6, jun, 2016. 
of $\boldsymbol{P}$ rigida. Larger root growth in low-water conditions is a drought-tolerance strategy, as the exploration of a larger volume of substrate potentially supplies the seedlings' water requirements. This was demonstrated by REIZ et al. (2006), who observed that intense root system growth was correlated with less sensitivity to water deficiency in hybrid eucalyptus clones.

The higher increase in shoot dry weight when the seedlings were submitted to an irrigation scheme of $4 \mathrm{~mm} \mathrm{~d}^{-1}$ can be explained by the fact that $\boldsymbol{P}$. rigida is known as an aggressive species that occurs naturally in a variety of soil types, including those with high drainage.

For the DQI, as well as for the dry weight variables (shoot, root, and total), there was no interaction between the irrigation schemes and the substrates $(\mathrm{F}=1.779 ; \mathrm{P}=0.067)$. However, there was a significant difference among the irrigation schemes $(\mathrm{F}=5.008 ; \mathrm{P}=0.002)$, with schemes of 4 and $8 \mathrm{~mm} \mathrm{~d}^{-1}$ delivering the highest values for this variable, 0.64 and 0.63 , respectively. DQI values based on substrate composition ranged from 0.57 with the use of peat alone to 0.38 with the addition of $60 \%$ carbonized rice husk.

DQI allows one to classify the quality of seedlings from morphological parameters; the higher the index, the better the quality of seedlings evaluated (GOMES, 2001). The index can be considered a good indicator of the quality of the seedlings, because its calculation uses the robustness and balance of the distribution of bioweight in seedlings, evaluating the results of several important parameters employed for the evaluation of quality (FONSECA et al., 2002).

For $\boldsymbol{P}$. rigida, the highest proportion of CRH (40 to $60 \%$ ) mixed with peat probably caused leaching of nutrients. Thus, substrates with appropriate proportions of CRH $(20 \%)$ mixed with peat provide more favorable conditions for the development of the seedlings for this species, with consequent reduction of production costs.

\section{CONCLUSION}

The use of substrate composed of $80 \%$ peat $+20 \%$ carbonized rice husk and/or the use of peat as a sole component, under an irrigation scheme of $4 \mathrm{~mm} \mathrm{~d}^{-1}$, delivers the best initial development of $\boldsymbol{P}$. rigida seedlings in the nursery. Such information is important for the production of superior quality seedlings, and provides a guideline for the rational use of resources.

\section{REFERENCES}

ALMEIDA, R.F. de. et al. Aspectos florísticos, históricos e ecológicos do componente arbóreo do Parque da Independência, São Paulo, SP. REVSBAU, v.5, n.3, p.1841, 2010. Available from: <http://www.revsbau.esalq.usp.br/ artigos_cientificos/artigo138-publicacao.pdf $>$. Accessed: Aug. 20, 2015.

ALVARES, C.A. et al. Köppen's climate classification map for Brazil. Meteorologische Zeitschrift, v.2 p.1-18, 2013.

AZEVEDO, M.I.R. Qualidade de mudas de cedro-rosa (Cedrela fissilis Vell.) e de ipê-amarelo (Tabebuia serratifolia (Vahl) Nich.) produzidas em diferentes substratos e tubetes. 2003. 90f. Dissertação (Mestrado em Ciência Florestal) - Universidade Federal de Viçosa, MG.

BACKES, P.; IRGANG, B. Árvores do Sul: guia de identificação e interesse ecológico. Porto Alegre: Paisagem do Sul, 2009, 325p.

CALDEIRA M.V.W. et al. Alternative substrates in the production of seedlings of Chamaecrista desvauxii. Revista Floresta, v.37, n.1, p.31-39, 2013. Available from: <http://www.scielo.br/ pdf/rarv/v37n1/v37n1a04.pdf $>$. Accessed: Jun. 09, 2014. doi: 10.1590/S0100-67622013000100004.

CARNEIRO, J.G.A. Produção e controle de qualidade de mudas florestais. Curitiba: FUPEF, 1995. 451p.

CARVALHO, P.E.R. Espécies arbóreas brasileiras. Brasília: EMBRAPA Informação Tecnológica. EMBRAPA FLORESTAS, 2003. V.1, 1039p.

DAVIDE, A.C.; FARIA, J.M.R. Viveiros florestais. In: DAVIDE, A.C.; SILVA, E.A.A. (Eds.). Produção de sementes e mudas de espécies florestais. Lavras:UFLA, 2008. Cap.2, p.83-124.

FERREIRA, D.F. Sisvar: a computer statistical analysis system. Ciência e Agrotecnologia (UFLA), v.35, n.6, p.1039-1042, 2011. Available from: <http://www.scielo.br/pdf/cagro/v35n6/ a01v35n6.pdf>. Accessed: Jun. 09, 2014. doi: 10.1590/S141370542011000600001

FONSECA, É.P. et al. Target seedlings of Trema micrantha (L.) blume grown under different periods of shading Revista Árvore, v.26, n.4, p.515-523, 2002. Available from: <http://www.scielo. br/pdf/rarv/v26n4/a15v26n4.pdf>. Accessed: Jul. 11, 2014. doi: 10.1590/S0100-67622002000400015.

GOMES, J.M. Parâmetros morfológicos na avaliação da qualidade de mudas de Eucalyptus grandis, produzidas em diferentes tamanhos de tubete e de dosagens de N-P-K. 2001. 126f. Tese (Doutorado em Ciência Florestal) - Universidade Federal de Viçosa, MG.

GONÇALVES, J.L.M. et al. Produção de mudas de espécies nativas: substrato, nutrição, sombreamento e fertilização. In: GONÇALVES, J.L.M.; BENEDETTI, V. (Eds.). Nutrição e fertilização florestal. Piracicaba: IPEF, 2000. p.309-350.

LOPES, J.L.W. Produção de mudas de Eucalyptus grandis W. (Hill ex. Maiden) em diferentes substratos e lâminas de irrigação. 2004. 100f. Dissertação (Mestrado em Irrigação e Drenagem) - Faculdade de Ciências Agronômicas, Universidade Estadual Paulista, SP. 
LOPES, J.L.W. et al. Quality of eucalyptus seedlings under different depths of irrigation and two substrastes. Revista Árvore v.31, n.5, p.835-843. 2007. Available from: $<$ http://www.scielo. br/pdf/rarv/v31n5/a07v31n5.pdf>. Accessed: Jul. 11, 2014. doi: 10.1590/S0100-67622007000500007.

MONDO, V.H.V. et al. Germination test of seeds of Parapiptadenia rigida (Benth.) Brenan (Fabaceae). Revista Brasileira de Sementes, v.30, n.2, p.177-183, 2008. Available from: <http:// www.scielo.br/pdf/rbs/v30n2/a22v30n2.pdf $>$. Accessed: Aug. 20, 2015. doi: 10.1590/S0101-31222008000200022.

MORGAN, J.M. Osmoregulation and water stress in higher plants. Annual Review Plant Physiology, v.2, p. 289-319, 1984.

ORTEGA, L.S. Temperamento de luz de los arboles del alto Paraná y potencial de regeneración forestal. Revista Forestal de Paraguay, v.11, n.1, p.16-20, 1995.

PATREZE, C.M.; CORDEIRO, L. Nitrogen-fixing and vesiculararbuscular mycorrhizal symbioses in some tropical legume trees of tribe Mimoseae. Forest Ecology and Management, v.196, n.7, p. 275-285, 2004. Available from: <http://www.sciencedirect. com/science/article/pii/S0378112704002701>. Accessed: Aug. 19, 2015. doi: 10.1016/j.foreco.2004.03.034.
REIZ, G.G. dos. et al. Performance of Eucalyptus spp. clones under different levels of soil water availability in the field - root and aboveground growth. Revista Árvore, v.30, n.6, p.921-931, 2006. Available from: <http://www.scielo.br/pdf/rarv/v30n6/ a07v30n6.pdf>. Accessed: Jul. 11, 2014. doi: 10.1590/S010067622006000600007.

RIO GRANDE DO SUL. Decreto Estadual n.47.137, de 30 de março de 2010. Institui o Programa Estadual de Recuperação de Áreas de Preservação Permanente-APP's e Reserva Legal, denominado Ambiente Legal, e dá outras providências. Available from: $<$ http://www.sema. rs.gov.br/sema/html/dec_47137.html>. Accessed: Jun.14, 2014.

TSUKAMOTO FILHO, A.A. et al. Regime de Regas e Cobertura de Substrato Afetam o Crescimento Inicial de Mudas de Myracrodruon urundeuva. Floresta e Ambiente, v.20, n.4, p.521-529, 2013. Available from: $<$ http://www.scielo.br/pdf/floram/v20n4/aop_027913. pdf $>$. Accessed: Jul. 15, 2014. doi: 10.4322/floram.2013.032.

VACCARO, S. et al. Aspectos da composição florística e categorias sucessionais do estrato arbóreo de três subseres de uma floresta estacional decidual, no Município de Santa Tereza-RS. Ciência Florestal, v.9, n.1, p.1-18, 1999. Available from: <http:// cascavel.ufsm.br/revistas/ojs-2.2.2/index.php/cienciaflorestal/ article/view/360/230>. Accessed: Jul. 15, 2014. 